\title{
Theme in Translation: A Systemic Functional Linguistic Perspective
}

\author{
Bo Wang \\ Centre for Translation Studies, The Hong Kong Polytechnic University \\ Hung Hom, Kowloon, Hong Kong
}

Received: 12-09-2014

Accepted: 25-10- 2014

Published: $31-10-2014$

doi:10.7575/aiac.ijclts.v.2n.4p.54

URL: http://dx.doi.org/10.7575/aiac.ijclts.v.2n.4p.54

\begin{abstract}
Since the 1990s, discourse analysis has been applied to translation studies, and studies with this approach have become quite prominent. As one resource of discourse analysis, the SFL (Systemic Functional Linguistics) model can be applied to analyze both the original text and the translated text. Following this approach, both texts are compared at the sociological, semiotic, generic, registerial, discoursal, and lexicogrammatical levels by adopting a top-down process. The applicability of Halliday's linguistic framework has then been widely recognized within the field of translation studies. Meanwhile, different strata of Systemic Functional Grammar have shed light on a number of studies. In this paper, I have restricted the topic to one aspect only, i.e. the textual metafunction. I have first traced the development of SFL and its integration with translation studies. Some basic terms in SFL and Theme/Rheme analysis are also explained. Then, some of the existing studies involving thematic analysis and translation are reviewed. As advocated by several scholars, what we need is a more objective apparatus for descriptive translation studies. It would be beneficial to link SFL and descriptive translation studies together, as SFL serves as a tool that relates linguistic choices to the sociocultural context systematically.
\end{abstract}

Keywords: Systemic Functional Linguistics, Textual Metafunction, Descriptive Translation Studies, Linguistic Choices

\section{Introduction}

The past fifty years have witnessed the rapid development of Systemic Functional Grammar (Halliday, 1961, 1985, 1994; Halliday and Matthiessen, 2004). As a theory of grammar, it is a resource of engaging with the grammar of all human language, and it offers an approach of viewing the grammar of a language in terms of how language is used. The grammar of language is interpreted as a system which helps people to interact with each other and to make sense of their world experiences (Martin, Matthiessen, \& Painter, 2010).

Systemic functional linguists, such as Halliday (2009), take the concept of translation as a relation between languages as well as a process of moving from one language into another. In either of the two perspectives, translation could be regarded as an extraordinary complicated achievement of the human brain. According to Halliday, translation is not only a specialized domain of research, but also a sort of testing ground for his theory. He holds that his theory would be inadequate if it could not give an account of the phenomenon of translation.

Since the founding of Systemic Functional Linguistics (SFL), various scholars have adopted this theory to study translation. Catford (1965) exploits Halliday's (1961) scale and category grammar which is an early version of Systemic Functional Grammar, and constructs a model of translation. He shows "how translation could be seen as a relationship between units in structures arranged in a hierarchy of ranks and levels" (Steiner, 2005: 485), and has thus been commonly recognized as one of the first scholars to apply systemic functional linguistics to translation.

From the mid-1970s onwards, Halliday's (1961) early version of the theory has been given increasing space to the system, which treats structure as "output of some configuration of systemic options" (Steiner, 2005: 486). It has become a semanticised grammar rather than the more formal one of the scale-and category version, and it has taken both context and text into consideration. The applicability of Halliday's $(1985,1994)$ linguistic framework has then been widely recognized within the field of translation studies (e.g. Newmark, 1987, 1991; Munday, 1997, 2001, 2002, 2008; Taylor, 1993).

Different strata of Systemic Functional Grammar have shed light on a number of studies (e.g. Baker, 1992; Hatim and Mason, 1990, 1997; House, 1977, 1997, 2006; Malmkjær, 2005; Matthiessen, 2001; Steiner, 1992, 1998, 2002, 2004; Trosberg, 2002). For instance, some researches are oriented towards the stratum of semantics. Baker (1992) as well as Hatim and Mason $(1990,1997)$ adopt several concepts from SFL, such as genre, register, cohesion, and coherence to their studies on the textuality of translation. In this way, equivalence has been examined on lexical, grammatical, textual and pragmatic levels. House $(1990,1997)$ provides a framework of translation quality assessment based on the Hallidayan theories of genre and register. She also incorporates pragmatic and cultural ideas, and expands text evaluation to a wider content.

Some later studies (e.g. Matthiessen, 2001; Teich, 2001, 2003) have become increasingly comprehensive. According to Erich Steiner (2005: 487), this "represents a movement of theorizing along the stratification dimension." For example, 
Matthiessen (2001) sketches the environments of translation and locates translation in a typology of systems as a semiotic process. In this way, translation has been studied within an overall SFL-architecture. Two translation clines are introduced, from the most global (widest) environments to the most local (narrowest) ones. Translation equivalence and translation shift are regarded as "two opposite poles on a cline of difference between languages (p. 78)." Six dimensions, which Matthiessen terms as the environments of translation are involved, i.e. stratification, instantiation, rank, metafunction, delicacy and axis. Equivalence and shift are then defined by these parameters. His study has offered a systemic map for future studies.

In this paper, I would restrict the topic to one aspect only, i.e. the textual metafunction. I will conduct a review on studies related to thematic development, both in terms of discourse analysis and translation studies. The current state of research in this area is expected to be addressed. Meanwhile, I would also give some suggestions for future studies.

\section{Thematic Development and Discourse Analysis}

\subsection{Systemic Functional Linguistics and Metafunctions}

Systemic functional linguistics has provided a detailed and systematic approach to analyze texts. According to Martin et al. (2010: 2), the main purpose for Halliday to create SFL "was not to orient the grammar to any single defined area of application, but to provide a general grammar for purposes of text analysis and interpretation". Therefore, "it is a grammar which provides a basic 'lingua franca' for text analysts working in a wide range of differing contexts; and it is very effectively organized as a tool of this kind" (ibid.).

Compared with formal grammar or traditional prescriptive grammar, systemic functional grammar is semantically richer, which could help discourse analysis become more insightful. An important dimension is added to the systemic analysis in that "it shows what a speaker chooses to mean in a given text against the background of what speakers can mean" (Martin et al., 2010: 3).

Clause is the basic unit in the SFL analysis. It is a combination of the different strands of meaning, which include "clause as a message (i.e. a quantum of information)", "clause as an exchange (i.e. a transaction between speaker and listener)", and "clause as a representation (i.e. a construal of some process in ongoing human experience)" (Halliday, 1994: 34).

Correspondingly, there are three metafunctions of a text, which include the ideational (clause as representation, which is realized by the experiential and logical meaning), the interpersonal (clause as exchange), and the textual (clause as message). With the help of a systemic analysis, these meanings would be jointly considered in the analysis. As it is shown in Figure 1, altogether four different strands of meaning are expected to be revealed.

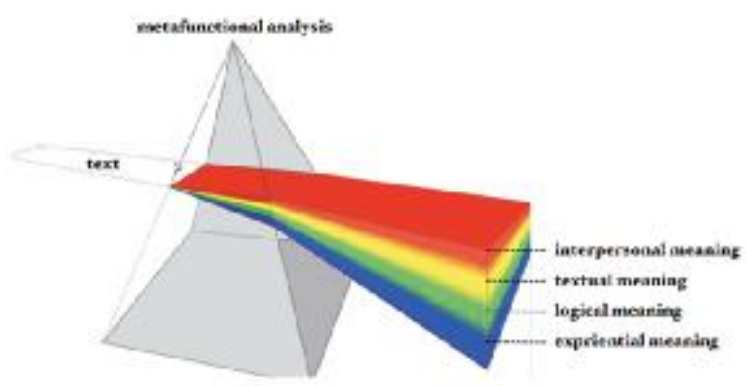

Figure 1. Modes of meaning in text revealed by the metafunctional part of discourse analysis. From Matthiessen, 2014: 277.

The textual metafunction is realized by the thematic structure and patterns of cohesion. Here in this paper, I would focus on the textual meaning which deals with the organization and structure of the clause and the text.

\subsection{Functions of Theme}

The concept of Theme is introduced by Mathesius in 1939. It originates from the works on functional sentence perspective (FSP) written by various Prague School scholars, such as Mathesius, Firbas, and Vaches.

Mathesius' view of Theme has then been accepted by most Prague School scholars. According to his definition, Theme refers to "that which is known or at least obvious in the given situation and from which the speaker proceeds" (Firbas, 1964: 286). Two aspects are covered in this definition, according to which thematic information includes: "(i) information which is known or obvious in the situation, (ii) information from which the speaker proceeds" (Fries, 1995a: 1). Halliday (1967, 1985) distinguishes the above-mentioned two notions. In Systemic Functional Grammar, the term Given is used to refer to the already known information (i.e. the first aspect), whereas Theme stands for "the point of departure of the message" (i.e. the second aspect). Fries (1995a) has differentiated these two approaches as "the combining approach" and "the splitting approach".

In the works of scholars on SFL, Theme and Information have been separated. In other words, Given and New as well as Theme and Rheme are all used as different terms. The elements of Given and New consist of the information structure, while Theme and Rheme partly comprise the thematic structure of the clause (Fries, 1995a). Thus, structures 
of Theme and Information impose different structure. "Information structure is imposed on the information unit (which is only indirectly associated with the clause). Thematic structure is part of the clause and other grammatical structures" (Fries, 1995a).

In the works by Halliday, the following definitions of Theme are found:

(i) The Theme is what is being talked about, the point of departure for the clause as message (Halliday, 1967: 212).

(ii) The English clause consists of a "Theme" and a "Rheme" ... (The Theme) is as it were the peg on which the message is hung... The Theme of the clause is the element which, in English, is put in first position; ... (Halliday, 1970: 161).

(iii) The Theme is the element which serves as the point of departure of the message; it is that with which the clause is concerned (Halliday, 1985: 38).

(iv) As a general guide, the Theme can be identified as that element which comes in first position in the clause. ... The Theme is one element in a particular structural configuration which, taken as a whole, organizes the clause as a message. ... A message consists of a Theme combined with a Rheme. Within that configuration, the Theme is the starting-point for the message; it is what the clause is going to be about (Halliday, 1985: 39).

(v) The Theme is the element which serves as the point of departure of the message; it is that with which locates and orients the clause within the context (Halliday and Matthiessen, 2004: 64).

In these definitions, some aspects summarized by Fries (1995a) deserve our attention. Firstly, Theme is regarded as a functional unit. This explains why the above-listed definitions are all descriptive, such as "point of departure for the clause as message" and "peg on which the message is hung". Secondly, the initial position of Theme is found in English. Whereas for other languages, Theme can be realized through other means, for example, the use of certain particles in Japanese, or affixes in Tagalog. A thorough systemic functional description of many languages are presented in Language Typology: A Functional Perspective (Caffarel, Martin and Matthiessen: 2004). Thirdly, although these descriptions are on the clause rank, thematic structures in fact exist on all ranks in English.

Following Halliday's definitions of Theme, some other distinctions are made, which could be helpful for discourse analysis. A Theme can be distinguished as marked or unmarked. In a declarative clause, a Theme would be a marked one if it is anything besides the Subject. If a Theme is the Subject, then it is unmarked. "The most usual form of marked Theme is an adverbial group, for example, today, suddenly, somewhat distractedly or prepositional phrase, such as at night, in the corner, without any warning functioning as Adjunt in the clause" (Halliday and Matthiessen, 2004: 73).

Besides, in one Theme, the first referential element which can either be the participant, circumstance, or process, is called "topical Theme". Before the topical Theme, there could be other elements, termed as "textual Themes" and "interpersonal Themes", whose functions are either textual or interpersonal.

Textual Themes could be continuatives, conjunctions (viz. structural Theme) or conjunctive Adjuncts; while interpersonal Themes could be modal or comment Adjuncts (viz. modal Theme), vocatives, or finite verbal operators in yes/no interrogatives. In most clauses, there are only one or two elements. However, if different sorts of these abovementioned Themes occur together, they have then become a multiple Theme. The different sorts of Themes are exemplified in the following table:

Table 1. An example of different types of Themes. Adapted from Halliday and Mattiessen, 2004: 81.

\begin{tabular}{|l|l|l|l|l|l|l|l|}
\hline well & but & then & surely & Jean & wouldn't & $\begin{array}{l}\text { the best } \\
\text { idea }\end{array}$ & $\begin{array}{l}\text { be } \\
\text { join in }\end{array}$ \\
\hline continuative & $\begin{array}{l}\text { conjunction } \\
\text { (structural } \\
\text { Theme })\end{array}$ & conjunction & $\begin{array}{l}\text { modal or } \\
\text { comment } \\
\text { Adjunt } \\
\text { (modal } \\
\text { Theme })\end{array}$ & vocative & finite & $\begin{array}{l}\text { topical } \\
\text { Theme }\end{array}$ & \\
\hline Textual Theme & \multicolumn{2}{|l|}{ Interpersonal Theme } & $\begin{array}{l}\text { Topical } \\
\text { Theme }\end{array}$ & Rheme \\
\hline
\end{tabular}

\subsection{Thematic Development and Discourse Analysis}

Thematic development can be applied to analyze various genres or registers, such as scientific discourse (Halliday, 1990), literary discourse (Goatly, 1995; Martin, 1995), academic discourse (Whittaker, 1995), sports commentary (Ghadessy, 1995a), etc. Linguists have benefited a great deal from thematic analyses. As Ventola (1995: 85) suggests, "in literary analysis, they (thematic analyses) give insight to the author's style; in language teaching they provide textstructuring help to novice writers ..."

In this part, I have chosen several papers from Thematic Development in English Texts edited by Mohsen Ghadessy (1995b) as well as other studies on different genres to answer the following two questions: (i) How Theme-Rheme can be used in discourse analysis? (ii) What are likely to be discovered by the analysis? 
Halliday (1990) chooses Charles Darwin's The Origin of Species for thematic analysis. He studies the structure of Theme and Rheme, and has observed some foregrounded features from the analysis. Though this is merely a partial analysis of only one part of the text, Darwin's strategy of writing has been identified, which is to accumulate masses of evidence rather than to move forward logically one step at a time. "And particularly at critical moments he moves into a more monumental mode, that of a writer producing a text which he knows is unique and will have a unique place in the history of ideas" (p. 74). At last, Halliday emphasizes the need of a scientific mode instead of "an ad hoc do-it-yourself kit of private commentary" (p. 74).

Ghadessy (1995a) conducts a Theme-Rheme analysis of the clauses in written sports commentaries. Different from the study reviewed above, the Themes are categorized into three types here in this paper, i.e. textual, interpersonal and ideational. Then the analyzed results are compared with findings on other genres and registers by Fries (1995b). Two of the hypotheses have been confirmed, namely: (i) Grammatical and lexico-semantic properties of Themes are different for different registers / genres. (ii) The frequency of Themes relate to the elements of structure in different registers / genres. In terms of grammatical and lexico-semantic properties, there is an obvious relationship between Theme selection and elements of structure. It is quite complex in that the differences between several genres and registers are compared. This study probes deeper into the thematic structure, as features on grammatical and lexicosemantic levels are involved. Ghadessy also suggests that studies of thematic development should complement with studies on mood and transitivity systems.

Martin (1995) presents a careful analysis of two texts, viz. an excerpt of P. D. James' detective novel Shroud for a Nightingale as well as a hortatory exposition from the Sydney Morning Herald. He agrees with the two steps pointed out by Fries and Francis (1992: 56) for the description of Themes in all languages: "(i) We must develop explicit descriptions of how Theme is realized in the various structures. (ii) We must develop a set of examples, arguments, and descriptions which demonstrate the uses and interpretation of Theme in context. These examples, arguments and descriptions should explicitly link Thematic content to the interpretation of texts." Martin suggests that "Theme in English means more than what the message is about. ... Significant patterns of information flow through Theme in ways that are critical to an interpretation of the meaning of a text" (p. 254). Finally, he emphasizes the need for linguists to offer their description of texts. Similar to the last two studies, this paper further proves the effectiveness of ThemeRheme analysis. The examples, arguments and descriptions have all successfully demonstrated the uses and interpretation of Theme in the context. Again, Theme-Rheme analysis is a scientific and objective way of discourse analysis. "Without this shared orientation to explaining language in use, contestation is just a waste of time" (p. 254).

Goatly (1995) chooses sixty-three poems of A Shropshire Land written by A. E. Houseman, and his analysis is from the stylistic perspective. He identifies the frequency and the significant patterns of marked Themes. Besides, he also successfully links theories of classical rhetoric and the loose work order of classical poetry with the poet's idiosyncratic use of marked Theme and the thematic development. The study arrives at a conclusion that "marked Theme linguistic analysis can achieve its stylistic status by bridging the gap between linguistics and literary criticism" (p. 196). Together with other researches that successfully links linguistic study with literature criticism, (e.g. Leech, 1969; Halliday, 1971), these studies all ensure the applicability of triangulating linguistic analysis with literary criticism or rhetorical theories.

Whittaker (1995) analyzes the textual and the ideational Themes in eight academic articles (i.e. four on economics and four on linguistics). Different types of Themes are identified and quantified, with a purpose of finding data to shed some light on teaching non-native students to write academic papers. Two major conclusions of this study are: Firstly, differences are found between the amount of textual and interpersonal Themes in two different genres, academic articles can thus be expected to have few interpersonal Themes. "Textual Themes are twice as frequent, and that this type of writing depends heavily on relational processes" (p. 124). Secondly, it is confirmed by the percentage of Theme type that writers of different genres adopt different strategies "to influence readers, generally without appearing to do so" while writing (p. 124). From this study, we can see that quantitative analysis is also an effective way of Theme-Rheme analysis. Meanwhile, like many other studies (e.g. Berry, 1995), the analysis of thematic pattern may have some pedagogical implications.

To sum up, the reviewed studies have proved that thematic development is applicable for the analysis of texts in different genres. In addition, with different methodologies, whether quantitative, qualitative or both, these studies have contributed to the variety of findings as well as further implications. Translation studies are also likely to benefit from the analysis of Theme and Rheme.

\section{Thematic Development in Translation Studies}

Since the 1990s, discourse analysis has been applied to translation studies, and studies with this approach have become quite prominent. As one resource of discourse analysis, the SFL model can be applied to analyze both the original text and the translated text. At the beginning of this paper, I have already sketched a brief history of its development. Following this approach, both texts are compared at the sociological, semiotic, generic, registerial, discoursal, and lexicogrammatical levels by adopting a top-down process (Eggins, 1994). Meanwhile, "the same texts are also located within their own sociocultural environment via a bottom-up process" (Mubenga, 2010: 271).

Further, as one of the central topics within the scope of SFL, the textual metafunction of discourse has thus drawn the attention of several scholars, with a number of studies being carried out. According to Kim and Matthiessen (forthcoming), the focus of many existing studies is the role of Theme and its impact on thematic progression. 
In the field of Systemic Functional Linguistics, translation is described by the different metafunctional modes of meaning: the ideational (experiential and logical), the interpersonal, and the textual. "If we see translation as centrally involving the recreation of meaning through choices made by the translator in the interpretation of the source text and through choices in the generation of the translated text, it follows that all modes of meaning are equally implicated: translation involves recreating ideational meanings of the logical kind, ideational meanings of the experiential kind, interpersonal meanings and textual meanings" (Kim and Matthiessen, forthcoming: 1). Traditionally, in translation studies, the focus has been mainly on experiential meaning, while the textual meaning has been neglected (House, 1997). However, an increasing number of studies in this field are still found in the literature, which has infused new thoughts to the translation studies of textual choices.

In this part, I would review some of the existing studies involving thematic analysis from the following three aspects: (i) whether the thematic structures in original and translated texts are preserved or not, (ii) theme selection as choice on the textual level, (iii) some frameworks that aim at answering the "meta-question" over the applicability of systemic functional linguistics to this area of translation studies.

\subsection{Thematic Structure in Translation}

\subsubsection{Studies Focused on Similar Thematic Structure}

Hasselgård (1998) examines whether thematic structure has been preserved or changed in translation. Eight texts are selected from the English-Norwegian Parallel Corpus. Four of them are excerpts from Norwegian novels with English translations, while the other four are English works translated to Norwegian. 150 sentences are randomly chosen from each excerpt, with a total amount of 600 pairs of sentences. The conclusion shows that a majority of sentences (i.e. $83 \%$ ) share the same Themes both in the original and the target language. As for the rest of the sentences, differences of Themes are caused by changes in the grammatical structure.

Nine political commentaries translated from English to Chinese are chosen by Ghadessy and Gao (2000) for a quantitative analysis of the thematic development. By comparing the original and target texts, some similarities and differences are found. Firstly, the majority of the additional Themes in Chinese are simple Themes. For multiple Themes, their amount does not differ significantly. Secondly, Chinese texts have more marked and unmarked Themes. Thirdly, there are more ellipted (omitted) Themes and times as Theme categories in Chinese texts. Based on these findings, the authors suggest that there is "a highly significant correlation between the Themes in English texts and Chinese translations in terms of assigned Themes features and Theme patterns selected" (p. 461). The analysis of the thematic patterns is expected to shed some light on writing teaching.

Liu and Yang (2013) analyze the thematic progression patterns of both the original text and the 11 translated versions of Francis Bacon's Of Studies. Like the two studies reviewed above, the thematic structure of the original work has been retained, and a basic interlingual correspondence among the texts is found. While English text favor the T2R1 type of thematic progression (i.e. the Theme of clause 2 is picked up from the Rheme of clause 1), the translated texts tend to adopt the T2T1 type (i.e. the Theme of clause 2 is picked up from the Theme of clause 1). The authors hold that their study verifies Venuti's (1995: 9) viewpoint that translation is "an inevitable domestication", which "always communicates a foreign text that is partial and altered, supplemented with features peculiar to the translating language". Meanwhile, the authors of this paper also indicate that the correspondence between thematic progression patterns is one of the norms in the descriptive study.

\subsubsection{Studies Focused on Different Thematic Structures}

Ventola (1995) explores the Theme/Rheme structures between German and English academic texts. Thematic progression and development in the parallel texts are discussed. It is suggested that the differences between the texts are related to the Theme-Rheme structures of the clauses and how the Given/New information is presented. As Halliday (1985) points out, the information structure coincides with the topical Theme-Rheme structure of the clause, so that in the unmarked cases, the topical Theme could also be the Given information, while the Rheme could be the New information. Based on previous studies on thematic development by Halliday (1985) and Weinrich (1993), this study illustrates how Theme/Rheme structures can be applied in texts, and it concludes that in academic registers, "the Theme/Rheme patterns are important in guiding the reader through the logical paths constructed by the writer" (Ventola, 1995: 102). Following Halliday (1961) and Koller's (1989) attempts of integrating theory and practice, it is indicated that translators should be trained to be aware of the thematic structure.

In another study, by studying the thematic and information structure between English and Portuguese translations, Vasconcellos (2008) emphasizes the variations between two languages and the translators' competence. It is concluded that "professional translators choose to preserve the original Theme and focus despite the constraints of a different target-language syntax" (p. 63). Meanwhile, the translator needs to take several aspects into consideration, such as "gaps in the lexicon, fusion of multiword concepts, differences in register, cultural differences, etc." (ibid.). He believes that it is impossible for a translator to capture all systems of meaning.

\subsection{The Selection of Theme as Choice}

Matthiessen $(2001,2014)$ views translation as recreation of meaning in context through choice. There are choices made by the translator during the interpretation of the original text as well as during the creation of the translated text. Translation is thus "an ongoing process of choosing options within the systems of the source language and of the target language" (2014: 2). Both in the interpretation of original text and in the generation of the translated text, there are 
always alternatives or options embodied in the meaning potentials for translators to choose. These choices are considered in terms of the metafunctional organization of language. As is previously mentioned, a text is constructed by different strands of meaning (see Figure 1). "In terms of textual meaning, translators choose how to interpret messages and the sequences of messages that create the flow of information in the source text, and they choose among the options in the target language to represent the textual meanings in the translation they are producing" (p. 7). Besides, these choices are made according to "the environment of the context in which the source text operates and in which the text being translated will operate" (ibid.).

Based on previous studies, Matthiessen (2014) identifies the various degrees of translation shifts in different metafunctions, and situates them on a cline (see Figure 2).

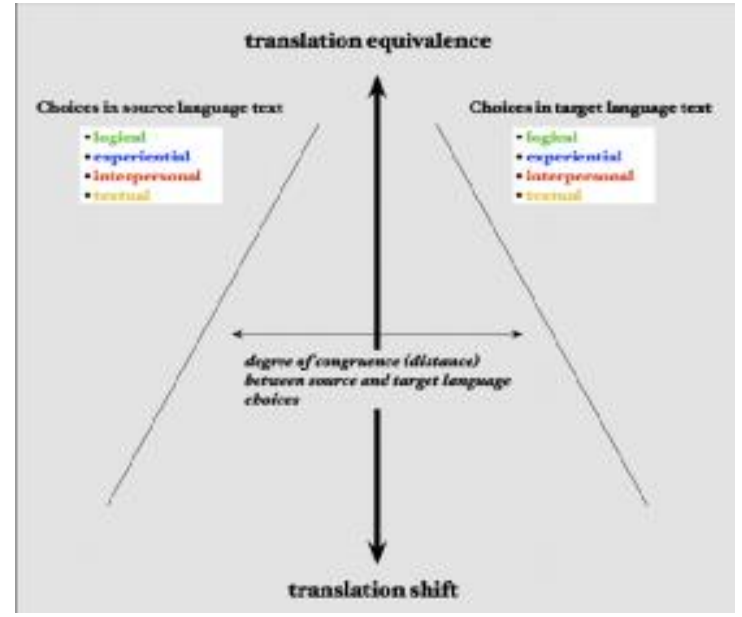

Figure 2. The cline from "translation equivalence" to "translation shift" as degree of congruence between source and target texts in terms of all four metafunctional modes of meaning. From Matthiessen, 2014: 2.

As is seen from Figure 2, "choices in one metafunction may be closer to the translation equivalence pole of the cline, while choices in another may be closer to the shift pole of the cline. Translation involves trade-offs in choices across the metafunctional spectrum" (p. 9). Different types of metafunctional shifts are summarized in the following matrix (see Figure 3). From the figure we can see that translation shifts in terms of textual function are categorized into two types, i.e. textual to textual, and textual to logical.

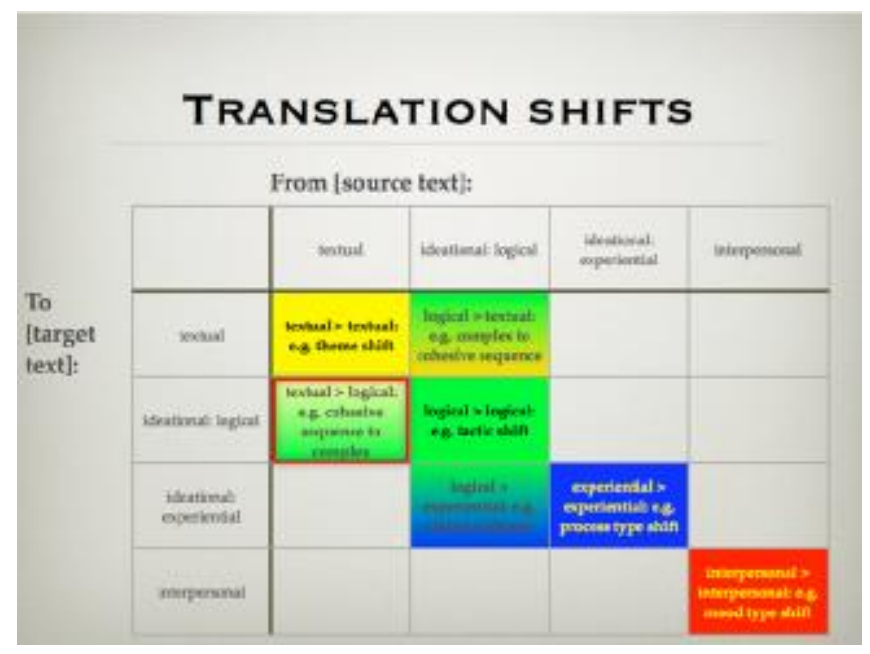

Figure 3. Matrix of metafunctional translation shifts. From Matthiessen, 2014: 13.

\subsection{The Applicability of SFL Models to Descriptive Translation Studies}

As early as the 1980s, Newmark (1987: 293) has noted the significance of linking SFL with translation studies. He has thus made the following remarks:

"Since the translator is concerned exclusively and continuously with meaning, it is not surprising that Hallidayan linguistics which sees language primarily as a meaning potential should offer itself as a serviceable tool for determining the constituent parts of a source language text and its network of relations with its translation."

The SFL approach is descriptive, and could naturally offer a methodology to the branch of descriptive translation studies initiated by Toury (1995). As Mubenga (2010) suggests, these procedures have meanwhile brought some changes to Toury's (1995: 36-39) three-phase methodology, which is as follows:

"(i) locating the TT in the target system to find its acceptability, 
(ii) mapping the TT onto the ST to determine the relationships between the TT and ST segments and study the translational shifts, and

(iii) formulating generalizations about the decisions made during the translation process and the norms of the TT and ST systems."

The change is, instead of first locating the TT in its own sociocultural environment, which Toury (1995) proposes, "the systemic functional model starts by analyzing both the ST and the TT down to the lexicogrammatical level in order to draw the profiles of linguistic and non-linguistic resources. These profiles are compared and relocated within their systemic context to identify the translational shifts and to deduce both the decisions and norms that were in operation" (Mubenga, 2010: 271).

Even-Zohar (1978) and Toury's (1980, 1995) approaches could investigate the norms in translation. Polysystem theory makes use of those regularities of translation behaviour within the social cultural environment. However, this theory is not without limitations. Since the polysystem theory is culture-bound, it has neglected the impact of ST (Yao, 2007). Thus, Halliday's $(1985,1994)$ SFL can be applied to translation studies. It is not an alternative to polysystem theory, but rather a complement to it.

To test the applicability of SFL to translation studies, several scholars have proposed their models based on SFL to study translation. For example, Munday (2002) has attempted to locate texts within their own sociocultural context. His model is an integration of the following approaches, i.e. Systemic Functional Linguistics, corpus linguistics, and an analysis of the cultural and social context. He holds that the SFL analysis has successfully identified the important aspects related to the shifts in translation. Textual metafunction is considered from the perspective of increased cohesion, Theme-Rheme pattern, sentence length and punctuation. Then, the corpus linguistic tools would "enable rapid manipulation of text and an uncovering of trends that may not be obvious to manual analysis" (p. 91). Finally, results of the analysis are set in the sociocultural and political context of texts, so as to enable "some conclusions to be drawn as to the norms at work in the translation process".

In other studies by Zhu Chunshen $(1993,1996,2008)$, he notes the importance of textual comparison in translation studies. He believes that language use in text formation is tri-stratal, and thus puts forward a three-dimensional model called Structure of Meaning (SOM).

This model integrates Halliday's $(1985,1994)$ Systemic Functional Grammar with Austin's (1975) speech act theory. According to Zhu (1996), Systemic Functional Grammar mainly focuses on the semantic structure of the text, while speech act theory concerns more about sentence in use. He holds that "the pattern of 'illocutionary force + information' on the sentence level can be applied to discourse analysis on the text level" (p. 345). Therefore, it is appropriate to link the two theories together. "The systemic functional model provides us with an insight into the mechanism of text creation in relation to language user, communication and situation, while the concept of speech act draws our attention to the illocutionary force and the perlocutionary effect of a text in actual communication, both models hinge on a threedimentional perception of text and text creation" (ibid.).

Zhu (1996) identifies the tri-stratal nature of language. Therefore, his framework is tri-stratal as well. The three dimensions of SOM framework are: (i) linguistic composition, which concentrates on the lexicogrammatical and phonological / graphological patterning; (ii) interactional dynamic, which emphasizes on interaction, and the exchange of meaning; (iii) aesthetic impact, whose focus "has shifted to information manipulation by textual means" (p. 347) to match the effect achieved by the original and the translated texts. For the SOM framework, each dimension is one part of the whole, "and each unit on the rank scale can potentially lend itself to comprehensive analysis as a SOM contributing to the composition of the SOM on a higher rank" (p. 346).

Our concern here is the second dimension of SOM, i.e. the interactional dynamic. The distribution of information, which is "textual in function (e.g. arrangement of Theme-Rheme patterns), but communicative in nature" (p. 347), is considered in this dimension. In actual practice, "translation in this dimension takes the whole text into account" (ibid.). Zhu holds that the translation methods that could be applied here in this dimension include communicative translation proposed by Peter Newmark $(1981,1988)$, and the main criterion is dynamic equivalence proposed by Eugene Nida (1964). The principal task for translation at this stage is "to convey the ideational and the interpersonal information, but not necessarily the stylistic significance of the textual function” (p. 347).

\section{Conclusions}

In this paper first traced the development of SFL and its integration with translation studies. Then, I have explained some basic terms in SFL and Theme-Rheme analysis, and have commented on some of the studies on the application of SFL on discourse analysis. In the next part, some existing studies related to the thematic development and translation are reviewed, with their focuses and outcomes identified.

For a long time, developments in linguistics have stimulated translation studies. In his monumental work Descriptive Studies and Beyond, Toury (1995) has developed a proper systematic descriptive branch of translation studies to replace the isolated free-standing studies. Toury demands systematic and replicable means for the analysis of ST-TT pairs. As advocated by several scholars (e.g. Munday, 2008), what we need is a more objective apparatus for descriptive translation studies. It would be beneficial to link SFL and descriptive translation studies together, as SFL "systematically relates linguistic choices to the sociocultural context" (Newmark, 1987; Munday, 2002, 2008). 
One of the purposes of writing this paper is to prove the suitability of constructing a model of translation studies based on Systemic Functional Grammar. More studies on this topic are expected to be carried out to either construct a more objective model or to develop descriptions of a multilingual meaning potential for the set of languages involved in translation, similar to what Bateman et al. (1999) have carried out in their research. After the scientific analysis, the next crucial task would be the interpretation of the result of the analysis.

\section{References}

Austin, J. (1975). How to do things with words. Oxford: Claredon Press.

Baker, M. (1992). In other words: A coursebook on translation. London and New York: Routledge.

Bateman, J. A., Matthiessen, C. M. I. M., \& Zeng, L. (1999). Multilingual language generation for multilingual software: A functional linguistic approach. Applied Artificial Intelligence: An International Journal, 13(6), 607-639.

Berry, M. (1995). Thematic options and success in writing. In M. Ghadessy (Ed.). Thematic development in English texts (pp. 55-84). London and New York: Pinter.

Caffarel, A., Martin, J. R., \& Matthiessen, C. M. I. M. (2004). Language typology: A functional perspective. Amsterdam: John Benjamins.

Catford, J. C. (1965). A linguistic theory of translation. London: Oxford University Presss.

Eggins, S. (1994). An introduction to systemic functional linguistics. London: Pinter.

Even-Zohar, I. (1978). The position of translated literature within the literary polysystem. In J. S. Holmes, J. Lambert, \& R. Broeck (Eds.), Literature and translation: New perspectives in literary studies (pp. 117-127). Leuven: Acco.

Firbas, J. (1964). On defining the theme in functional sentence analysis. Traveaux Linguistiques de Prague, 1, $267-280$.

Fries, P. H. (1995a). A personal view of theme. In M. Ghadessy (Ed.). Thematic development in English texts (pp. 119). London and New York: Pinter.

Fries, P. H. (1995b). Themes, methods of development, and texts. On Subject and Theme: A Discourse Functional Perspective, 118, 317.

Fries, P. H., \& Francis, G. (1992). Exploring theme: Problems for research. Occasional Papers in Systemic Linguistics, $5,45-60$.

Ghadessy, M. (1995a). Thematic development and its relationship to registers and genres. In M. Ghadessy (Ed.). Thematic development in English texts (pp. 129-146). London and New York: Pinter.

Ghadessy, M. (Ed.) (1995b). Thematic development in English texts. London and New York: Pinter.

Ghadessy, M., \& Gao, Y. (2000). Thematic organization in parallel texts: Same and different methods of development. Text, 20(4), 461-488.

Goatly, A. (1995). Marked theme and its interpretation in A. E. Houseman's A Shropshire Land. In M. Ghadessy (Ed.). Thematic development in English texts (pp. 164-197). London and New York: Pinter.

Halliday, M. A. K. (1961). Categories of the theory of grammar. Word, 17, 241-292.

Halliday, M. A. K. (1967). Notes on transitivity and theme in English, part II. Journal of Linguistics, 3: 177-274.

Halliday, M. A. K. (1970). Language structure and language function. In John Lyons (Ed.), New horizons in linguistics (pp. 140-164). Harmondsworth: Penguin.

Halliday, M. A. (1971). Linguistic function and literary style: An inquiry into the language of William Golding's The Inheritors. In S. B. Chatman (Ed.), Literary style: A symposium (pp. 330-365). London and New York, Oxford University Press.

Halliday, M. A. K. (1985). An introduction to functional grammar. London: Edward Arnold.

Halliday, M. A. K. (1990). The construction of knowledge and value in the grammar of scientific discourse: With reference to Charles Darwin's The Origin of Species. In C. de Stasio, M. Gotti, \& R. Bonadei (Eds.), La rappresentazione verbale e iconica: valori estetici e funzionali (pp. 57-80). Milan: Guerini Studio.

Halliday, M. A. K. (1994). An introduction to functional grammar (2nd edition). London: Edward Arnold.

Halliday, M. A. K. (2009). The gloosy gandoderm: Systemic functional linguistics and translation. Chinese Translators Journal, 1, 17-26.

Halliday, M. A. K. \& Matthiessen, C. M. I. M. (2004). An introduction to functional grammar (3rd edition). London: Edward Arnold.

Hasselgård, H. (1998). Thematic structure in translation between English and Norwegian. In S. Johanssion, \& S. Oksefjell (Eds.). Corpora and cross-linguistic research (pp. 145-168). Amsterdam: Rodopi.

Hatim, B., \& Mason, I. (1990). Discourse and the translator. London: Longman.

Hatim, B., \& Mason, I. (1997). The translator as communicator. London: Routledge.

House, J. (1977). A model for translation quality assessment. Tübingen: Gunter Narr. 
House, J. (1997). Translation quality assessment: A model revisited. Tübingen: Gunter Narr.

House, J. (2006). Text and context in translation. Journal of Pragmatics, 38, 338-358.

Kim, M., \& Matthiessen, C. M. I. M. (forthcoming). Ways to move forward in translation studies: A textual perspective.

Koller, W. (1989). Lingvistisen lähestymistavan mahdollisuudet ja rajat käännöstieteessä (The possiblitilies and boundaries of linguistics in translation theory). In R. Jokisaari (Ed.). Kääntäminen ja kielten opetus (Translation and teaching languages) (pp. 19-36). Helsinki: Helsinki University Press.

Leech, G. N. (1969). A linguistic guide to English poetry. London: Longman.

Liu, X., \& Yang, X. (2013). Thematic progression in English-Chinese translation of argumentative classics: A quantitative study of Francis Bacon's 'Of Studies' and its 11 Chinese translations. Perspectives: Studies in Translatology, 21(2), 272-288.

Malmkjær, K. (2005). Linguistics and the language of translation. Edinburgh: Edinburgh University Press.

Martin, J. R. (1995). More than what the message is about: English theme. In M. Ghadessy (Ed.). Thematic development in English texts (pp. 223-258). London and New York: Pinter.

Martin, J. R., Matthiessen, C. M. I. M., \& Painter, C. (2010). Deploying functional grammar. Beijing: Commercial Press.

Matthiessen, C. M. I. M. (2001). The environments of translation. In E. Steiner \& C. Yallop (Eds.). Exploring translation and multilingual text production: Beyond content (pp. 41 - 124). Berlin: Mouton de Gruyter.

Matthiessen, C. M. I. M. (2014). Choice in translation: Metafunctional considerations. In Kerstin Kunz, Elke Teich, Silvia Hansen-Schirra, Stella Neumann \& Peggy Daut (Eds.). Caught in the Middle-Language Use and Translation: $A$ Festschrift for Erich Steiner on the Occasion of his 60th Birthday (pp. 271 - 333). Saarland: Saarland University Press.

Mubenga, K. S. (2010). Investigating norms in interlingual subtitling: A systemic functional perspective. Perspectives: Studies in Translatology, 18(4), 251-274.

Munday, J. (1997). Systems in translation: A computer-assisted systemic analysis of the translation of Garcia Márquez. (Unpublished doctoral dissertation). University of Bradford, Bradford.

Munday, J. (2001). Introducing translation studies: Theories and applications. London and New York: Routledge.

Munday, J. (2002). Systems in translation: A systemic model for descriptive translation studies. In T. Hermans (Ed.), Crosscultural transgressions: Research models in translation studies II: Historical and ideological issues (pp. 7692). Manchester: St Jerome.

Munday, J. (2008). Problems of applying thematic analysis to translation between Spanish and English. Cadernos de Tradução, 1(3), 183-213.

Newmark, P. (1981). Approaches to translation. Oxford and New York: Prentice Hall.

Newmark, P. (1987). The use of systemic linguistics in translation analysis and criticism. In R. Steele, \& T. Threadgold (Eds.), Language topics: Essays in honor of Michael Halliday (Vol. 1). Amsterdam and Philadelphia: John Benjamins.

Newmark, P. (1988). A textbook of translation. Oxford and New York: Prentice Hall.

Newmark, P. (1991). About translation. Clevedon: Multilingual Matters.

Nida, E. (1964). Towards a science of translation: With special reference to principles and procedures involved in Bible translating. Leiden: Brill.

Steiner, E. (1992). Some remarks on a functional level for machine translation. Language Sciences, 14(4), 623-659.

Steiner, E. (1998). A register-based translation evaluation. Target, 10 (2): 291-318.

Steiner, E. (2002). Grammatical metaphor in translation: Some methods for corpus-based investigations. In H. Hasselgård, S. Johansson, B. Behrens, \& C. Fabricius-Hansen (Eds.). Information structure in a cross-linguistic perspective (pp. 213-228). Amsterdam: Rodopi.

Steiner, E. (2004). Translated texts: Properties, variants, evaluations. Peter Lang.

Steiner, E. (2005). Halliday and translation theory - enhancing the options, broadening the range, and keeping the ground. In R. Hasan, C. M. I. M. Matthiessen, \& J. Webster (Eds.). Continuing discourse on language: A functional perspective (Volume 1) (pp. 481-500). London: Equinox.

Taylor, C. (1993). Systemic linguistics and translation. Occasional Papers in Systemic Linguistics 7, 87-103.

Teich, E. (2001). Towards a model for the description of cross-linguistic divergence and commonality in translation. In E. Steiner \& C. Yallop (Eds.). Exploring translation and multilingual text production: Beyond content (pp. $41-124)$. Berlin: Mouton de Gruyter.

Teich, E. (2003). Cross-linguistic variation in system and text: A methodology for the investigation of translations and comparable texts. Berlin and New York: Mouton de Gruyter.

Trosborg, A. (2002). Discourse analysis as part of translator training. In C. Schäffner (Ed.). The role of discourse analysis for translation and in translator training (pp. 9-52). Clevedon: Multilingual Matters. 
Toury, G. (1980). In search of a theory of translation. Tel Aviv: The Porter Institute.

Toury, G. (1995). Descriptive translation studies and beyond. Amsterdam: Benjamins.

Vasconcellos, M. H. de. (2008). Text and translation: The role of theme and information. Ilha do Desterro: A Journal of English Language, Literature in English and Cultural Studies, 27, 45-66.

Ventola, E. (1995). Thematic development and translation. In M. Ghadessy (Ed.). Thematic development in English texts (pp. 85-104). London and New York: Pinter.

Venuti, L. (1995). The translator's invisibility: A history of translation. London and New York: Routledge.

Weinrich, H. (1993). Textgrammatik der deutschen Sprache. Mannheim, Leipzig, Wein and Zürich: Duden Verlag.

Whittaker, R. (1995). Theme, processes and the realization of meanings in academic articles. In M. Ghadessy (Ed.). Thematic development in English texts (pp. 105-128). London and New York: Pinter.

Yao, W. (2007). Norms, polysystems and ideology: A case study. The Translator, 13(2), 321-339.

Zhu, C. (1993). Structure of meaning (SOM): Towards a three-dimensional perspective on translating between Chinese and English. (Unpublished doctoral dissertation). University of Nortingham, Nortingham.

Zhu, C. (1996). From functional grammar and speech act theory to structure of meaning: A three-dimensional perspective on translating. Meta, XLI(3), 338-355.

Zhu, C. (2008). Fanyi tanwei: Yuyan, wenben, shixue. Jiangsu: Yilin Press. 